\title{
Photodegradation of Nitrogen Oxide under Solar Light Using a Facile Synthesis Catalyst
}

\section{Aerosol and Air Quality Research}

\section{OPEN ACCESS}

Received: June 3, 2021

Revised: August 10, 2021

Accepted: August 13, 2021

${ }^{*}$ Corresponding Author:

\section{Publisher:}

Taiwan Association for Aerosol Research

ISSN: $1680-8584$ print ISSN: 2071-1409 online

\section{Copyright: The Author(s).} This is an open access article distributed under the terms of the Creative Commons Attribution License (CC BY 4.0), which permits unrestricted use, distribution, and reproduction in any medium, provided the original author and source are cited.

\author{
Ernso Fenelon ${ }^{1,2}$, Sheng-Jie You ${ }^{2,3}$, Ya-Fen Wang ${ }^{2,3 *}$ \\ ${ }^{1}$ Department of Civil Engineering, Chung Yuan Christian University, Taoyuan 32023, Taiwan \\ ${ }^{2}$ Department of Environmental Engineering, Chung Yuan Christian University, Taoyuan 32023, \\ Taiwan \\ ${ }^{3}$ Center for Environmental Risk Management, Chung Yuan Christian University, Taoyuan 32023, \\ Taiwan
}

\section{ABSTRACT}

$\mathrm{NO}_{\mathrm{x}}$ is becoming a hot issue due to its contribution to ozone, $\mathrm{PM}_{2.5}$ formation, and its negative impacts on the ecosystem. In this study, the synthesis of an $\mathrm{MgO} / \mathrm{Bi}_{2} \mathrm{~S}_{3}-\mathrm{BiOCl}$ composite was carried out via the co-precipitation method for the photodegradation of nitrogen oxide (NO) under solar light. The $\mathrm{BiOCl}$ heterojunction is a result of interactions between the $\mathrm{Bi}_{2} \mathrm{~S}_{3}$ solution and the $\mathrm{MgCl}_{2} .6 \mathrm{H}_{2} \mathrm{O}$ precursor. This $\mathrm{BiOCl}$ heterojunction provides more available active species that enhance the degradation of NO. The successful synthesis of this composite using a co-precipitation method was confirmed by different characterization analyses (XRD, FTIR, SEM, TEM, DRS, and ESR). The photocatalytic degradation of $\mathrm{NO}$ under solar light using $7 \% \mathrm{MgO} / \mathrm{Bi}_{2} \mathrm{~S}_{3}-\mathrm{BiOCl}$ reached an efficiency of $74.6 \%$, which was better than that obtained using pure $\mathrm{Bi}_{2} \mathrm{~S}_{3}(42.8 \%)$ and $\mathrm{MgO}$ (11.2\%). The reusability test showed that the $7 \% \mathrm{MgO} / \mathrm{Bi}_{2} \mathrm{~S}_{3}-\mathrm{BiOCl}$ material was maintained stability in the photodegradation of $\mathrm{NO}$ even after five cycles. The trapping test showed that the holes $\left(\mathrm{h}^{+}\right)$and hydroxyl $\left({ }^{\circ} \mathrm{OH}^{-}\right)$were the main active factors in the photodegradation process. The findings of this study confirmed that $\mathrm{MgCl}_{2} \cdot 6 \mathrm{H}_{2} \mathrm{O}$ is a suitable precursor leading to improvements in the performance of $\mathrm{Bi}_{2} \mathrm{~S}_{3}$ for the purpose of promoting a new composite that can be used in the photodegradation of $\mathrm{NO}$ and could be a candidate for practical applications.

Keywords: $\mathrm{MgO} / \mathrm{Bi}_{2} \mathrm{~S}_{3}-\mathrm{BiOCl}$, Photocatalysis, Nitrogen oxide, Solar light

\section{INTRODUCTION}

NO is a harmful pollutant that is principally generated by car engines and industrial power plants. It contributes to acid rain, air pollution, and ozone depletion (Biswas and Mahajan, 2021; Biswas et al., 2021; Chen et al., 2017; Liu et al., 2019; Wang et al., 2020; Yu et al., 2020). It is also responsible for the genesis of small particulate matter $(P M)$, especially $P_{2.5}$, which is very dangerous to human beings (Huang et al., 2017; Li et al., 2015; Wang et al., 2016; Zhao et al., 2016). Many methods have been applied to reduce and control the effects of NO in the environment, including denitrification of $\mathrm{NO}_{\mathrm{x}}$ emissions, (de- $\mathrm{NO}_{\mathrm{x}}$ ) technologies (Yan et al., 2018), electron beam irradiation, adsorption, wet absorption, selective catalytic reduction (SCR), and selective non-catalytic reduction (Yan et al., 2018). In addition to all the remediation methods, the use of a photocatalyst is a process of generating energy by using chemical reactions with light energy at an optimum point for the purpose of degrading environmental pollutants (Fenelon et al., 2019; Feng et al., 2019; John et al., 2021; Neves et al., 2017) and is regarded as a "clean" and productive process (Nguyen et al., 2019).

When applying a high-quality catalytic, it is necessary to obtain better performance at low temperatures and to reduce application costs (Zhang et al., 2020). Both conventional and developing catalysts, such as $\mathrm{TiO}_{2}, \mathrm{ZnO}, \mathrm{SnO}_{2}, \mathrm{Cu}_{2} \mathrm{O}, \mathrm{Bi}_{2} \mathrm{~S}_{3}, \mathrm{~g}_{-} \mathrm{C}_{3} \mathrm{~N}_{4}, \mathrm{Bi}_{2} \mathrm{WO}_{6}$, and $\mathrm{BiPO}_{4}$, among others, are typically applied for the reduction of environmental pollutants, including NO (Li et al., 2019; Nguyen et al., 
2019). Unfortunately, their performance is usually limited either by a large band-gap or rapid photogeneration of recombination electrons $\left(\mathrm{e}^{-}\right)$and holes $\left(\mathrm{h}^{+}\right)$. Some studies in the previous literature on this topic also suggest limitations in these catalysts due to low degradation of NO under visible light, solar light, and UV light. A new photocatalyst is therefore needed to improve the photodegradation of NO. Among various available catalysts, $\mathrm{Bi}_{2} \mathrm{~S}_{3}$ is an excellent semiconductor that has drawn broad attention related to thermoelectric devices (Guo et al., 2013), super capacitor electrodes (Nie et al., 2015), sensors (Sun et al., 2016), solar cells (Li et al., 2016), and Schottky diodes (Bao et al., 2008). Additionally, photocatalysts based on $\mathrm{Bi}_{2} \mathrm{~S}_{3}$ are very appealing for the following reasons: (1) The narrow band-gap implies broad photo-absorption ability, which is favored for photocatalytic activity, and (2) raw resources including bismuth and sulfide are plentiful at the global level and thus easily accessible at a low cost. However, pure $\mathrm{Bi}_{2} \mathrm{~S}_{3}$ is limited in terms of achieving high performance in the conversion of solar energy because of its small optical band-gap $(1.3 \mathrm{eV})$ and thus has been restricted to the easy recombination of photogenerated $\mathrm{e}^{-}$ $-\mathrm{h}^{+}$pairs (Long et al., 2015).

To overcome the above-reverenced problems related to the photocatalytic efficiency of $\mathrm{Bi}_{2} \mathrm{~S}_{3}$ under solar light, an $\mathrm{MgO}$ material was applied as a new companion to improve the performance of $\mathrm{Bi}_{2} \mathrm{~S}_{3}$. In this study, $\mathrm{MgO}$ was selected because of its low heat power and because it is chemically inert, has high optical clarity, and is thermally stable (Gao et al., 2012). In addition, the presence of the $\mathrm{BiOCl}$ compound leads to a heterojunction that typically forms in the preparation of a $\mathrm{Bi}_{2} \mathrm{~S}_{3}$ material with a precursor that contains $\mathrm{Cl}$ ions in water solvent (Fenelon et al., 2020; Guan et al., 2013; Lei et al., 2009; Zhang et al., 2014). Therefore, the $\mathrm{MgO} / \mathrm{Bi}_{2} \mathrm{~S}_{3}-\mathrm{BiOCl}$ composite discussed in this work was developed in a solution of $\mathrm{Bi}_{2} \mathrm{~S}_{3}$ with the $\mathrm{MgCl}_{2} \cdot 6 \mathrm{H}_{2} \mathrm{O}$ precursors in water, and its efficacy was successfully confirmed using a characterization analysis. Additionally, the presence of $\mathrm{BiOCl}$ was found to be beneficial for photocatalytic activities due to the availability of more active species leading to the generation of electron-hole pairs and the fact that it enhances the performance of the composite. This study involves taking advantage of this composite, which is synthesized for the first time using a co-precipitation method for potential application in the photodegradation of NO assisted by solar light.

\section{MATERIALS AND METHOD}

\subsection{Materials and Chemicals}

Xilong Chemical Co., Ltd., Beijing, China, provided the bismuth nitrate $\left(\mathrm{Bi}\left(\mathrm{NO}_{3}\right) 3 \mathrm{H}_{2} \mathrm{O}\right)$ chemical at a weight fraction of 0.990. Magnesium Chloride Hexahydrate (BioXtra, $\geq 99.0 \%$ ), isopropyl alcohol (IPA, Merck, 99.99\%), ethanol $\left(\mathrm{C}_{2} \mathrm{H}_{6} \mathrm{O}\right)$, sodium hydroxide $(\mathrm{NaOH}, 99 \%)$, Thiourea $\left(\mathrm{CH}_{4} \mathrm{~N}_{2} \mathrm{~S}\right.$, China, 99.9\%) were utilized in this study, as well as double-distilled water (DDW).

\subsection{Synthesis of $\mathrm{Bi}_{2} \mathrm{~S}_{3}, \mathrm{MgO}$ Nanoparticles, and $\mathrm{MgO} / \mathrm{Bi}_{2} \mathrm{~S}_{3}-\mathrm{BiOCl}$ Composites}

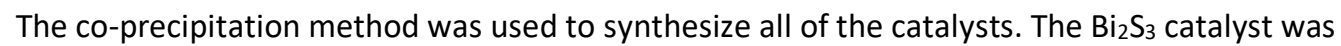
prepared by mixing $5.174 \mathrm{~g}$ of $\mathrm{Bi}\left(\mathrm{NO}_{3}\right)_{3} .5 \mathrm{H}_{2} \mathrm{O}$ and $133.34 \mathrm{ml}$ of double-distilled water (DDW), after which $1.2 \mathrm{~g}$ of $\mathrm{CH}_{4} \mathrm{~N}_{2} \mathrm{~S}$ was applied in $13.34 \mathrm{ml}$ of DDW separately mixed for $30 \mathrm{~min}$. After the mixing time, a thiourea solution was introduced into the solution of $\mathrm{Bi}\left(\mathrm{NO}_{3}\right)_{3} .5 \mathrm{H}_{2} \mathrm{O}$ and constantly mixed for $60 \mathrm{~min}$. Afterward, a yellow solution was recovered and washed at least four times using DDW and $\mathrm{C}_{2} \mathrm{H}_{6} \mathrm{O}$ at a ratio of 5:1 to remove all of the impurities. Finally, the $\mathrm{Bi}_{2} \mathrm{~S}_{3}$ sample was dried at $60^{\circ} \mathrm{C}$ for 12 hours and then calcinated at $400^{\circ} \mathrm{C}$ for 2 hours.

Synthesis of the $\mathrm{MgO}$ material was carried out using the same precipitation method. $5.1 \mathrm{~g}$ of $\mathrm{MgCl}_{2} .6 \mathrm{H}_{2} \mathrm{O}$ was put into a mixed solution of $80 \mathrm{~mL}$ of DDW. After that, the $\mathrm{NaOH}$ solutions were added to adjust the solution to $\mathrm{pH} 10$ for the purpose of facilitating the oxidation of magnesium, after which it was mixed for 2 hours. Finally, the substance was rinsed with ethanol and DDW, dried at $60^{\circ} \mathrm{C}$ for 12 hours, and then calcined at $400^{\circ} \mathrm{C}$ for 2 hours.

Synthesis of the $\mathrm{MgO} / \mathrm{Bi}_{2} \mathrm{~S}_{3}-\mathrm{BiOCl}$ composites (Fig. 1) was carried out using different weight percentages of $\mathrm{MgO}$ and $\mathrm{Bi}_{2} \mathrm{~S}_{3}(5 \%, 7 \%, 10 \%$, and $15 \% \mathrm{MgO})$. A solution of synthesized $\mathrm{MgO}$ was added dropwise into the $\mathrm{Bi}_{2} \mathrm{~S}_{3}$ solution and mixed for 3 hours. Finally, the material was washed four times with $\mathrm{C}_{2} \mathrm{H}_{6} \mathrm{O}$ and DDW, centrifuged, dried at $60^{\circ} \mathrm{C}$ for 12 hours, and then calcinated at $400^{\circ} \mathrm{C}$ for 2 hours. 


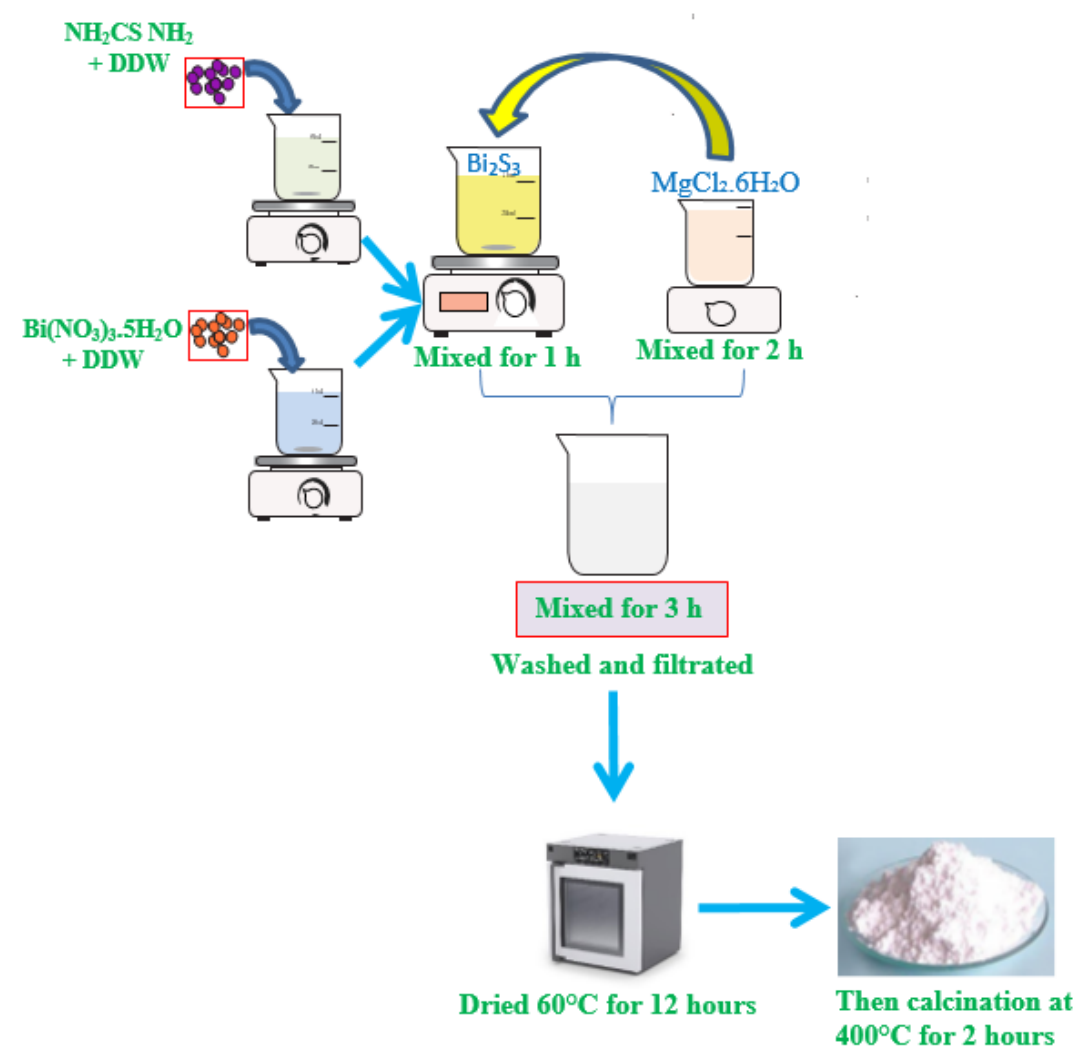

Fig. 1. Synthesis of the $\mathrm{MgO} / \mathrm{Bi}_{2} \mathrm{~S}_{3}-\mathrm{BiOCl}$ composites.

\subsection{Surface Analysis}

Scanning and transmission electron microscopy (SEM, TEM) were applied to study the morphology of the materials. The crystal structure and phase composition were analyzed using an X-ray diffraction (XRD) pattern on a Bruker D8-Advance 5005 with Cu K radiation of $0.154064 \mathrm{~nm}$. The feature group and bonding of the catalyst were calculated using Fourier transform infrared spectroscopy (FTIR). Using a UV-Vis spectrometer, the optical properties of the composites were determined using UV-vis diffuse reflectance spectroscopy (DRS) in a wavelength range of 200$800 \mathrm{~nm}$ (JASCO-V550). Using a Bruker EMX Plus X-Band spectrometer, the electron spin resonance (ESR) with DMPO (5,5-Dimethyl-1-Pyrroline N-oxide) was used to analyze the ESR signals of the reactive oxygen species (ROSs) produced in the photodegradation activity, and Malvern Panalytical's Zetasizer Nano ZS was used to determine the particle size of the preparation material.

\subsection{Pollutant Photocatalytic Degradation Measurements}

The photocatalytic activity of the material shown in Fig. 2 was assessed by analyzing the photodegradation potential of nitrogen oxide using $500 \mathrm{ppb}$ with a continuous flow reactor set at $3 \mathrm{~L} \mathrm{~min}{ }^{-1}$ at room temperature. A $300 \mathrm{~W}$ Xenon lamp 135 (Perfect Light MICRO SOLAR 300, Beijing, China) was used for solar light irradiation. $0.20 \mathrm{~g}$ of the photocatalysts were added to $20 \mathrm{~mL}$ of DDW and transferred to a glass dish $(\mathrm{d}=12 \mathrm{~cm})$, followed by drying at $80^{\circ} \mathrm{C}$ and placing in the center of the reactor. After the catalyst reached adsorption/desorption balance at $480 \mathrm{ppb}$, the lamp was turned on while maintaining a humidity of $40 \%$. A NOx analyzer was continuously used to track the concentration of NO. The NO degradation was calculated using $\mathrm{C} / \mathrm{CO}$, in which $\mathrm{C}$ represents the current $\mathrm{NO}$ concentration in the exit, and $\mathrm{CO}$ is the original NO contamination. For the trapping test, different scavengers of $10^{-3} \mathrm{M}$ were added to the catalyst. Potassium iodide ( $\mathrm{KI}$ ), isopropyl alcohol (IPA), and potassium dichromate $\left(\mathrm{K}_{2} \mathrm{Cr}_{2} \mathrm{O}_{7}\right)$ were used as effective scavengers of the holes, hydroxyl radicals, and photogenerated electrons, respectively, in this procedure. The kinetics $\mathrm{K}=\left(\operatorname{In}\left(\mathrm{C} / \mathrm{C}_{0}\right)\right) / \mathrm{t}$ of the photocatalysts were measured using the obvious first-order rate constant $\mathrm{k}\left(\mathrm{min}^{-1}\right)$ of $\mathrm{NO}(\mathrm{ppbV})$ at the initial $\mathrm{CO}$, and $\mathrm{C}$ is the final concentration at different time ( $\mathrm{min}$ ) (Pham et al., 2020). 


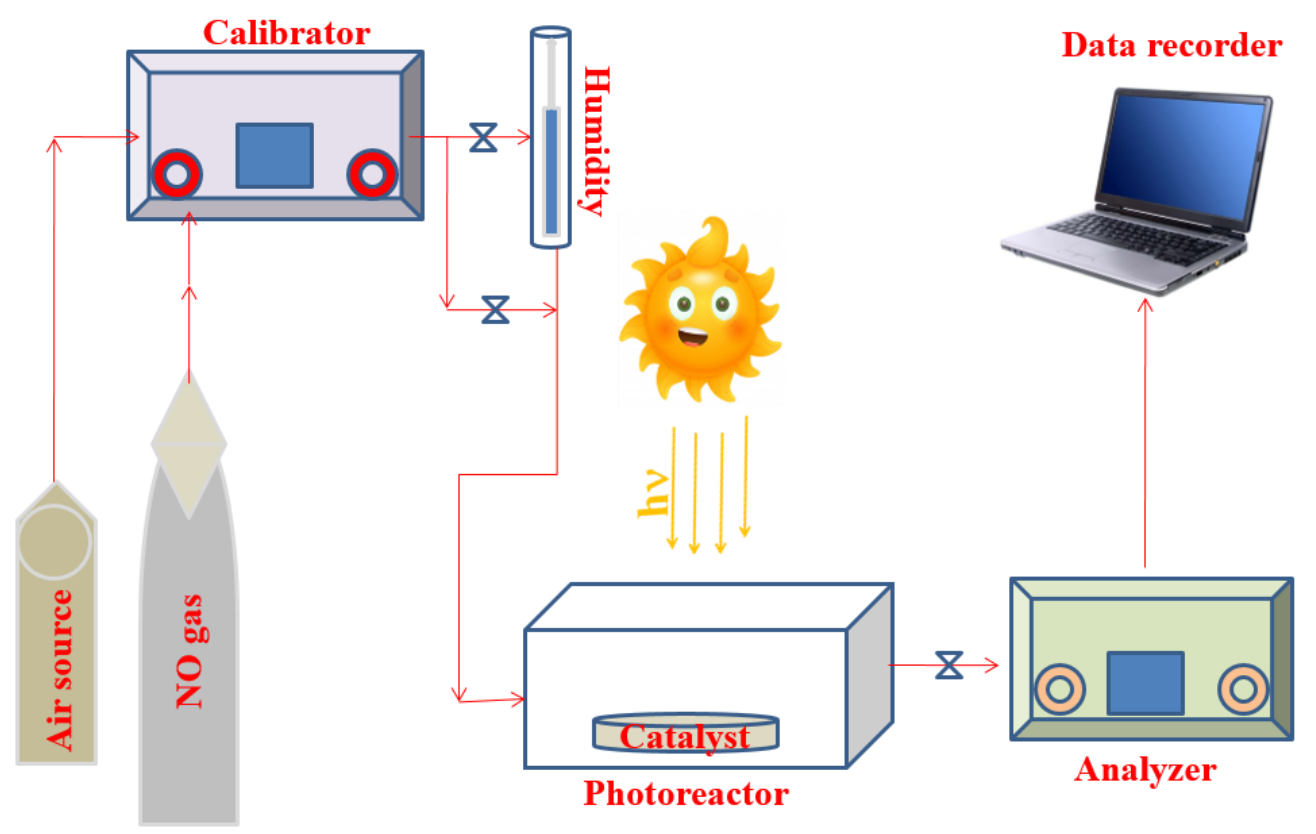

Fig. 2. Photodegradation of NO.

\section{RESULTS AND DISCUSSION}

\subsection{XRD Pattern Analysis}

The XRD analysis of $\mathrm{MgO}, \mathrm{Bi}_{2} \mathrm{~S}_{3}$, and $\mathrm{MgO} / \mathrm{Bi}_{2} \mathrm{~S}_{3}-\mathrm{BiOCl}$ is shown in Fig. 3. The $\mathrm{Bi}_{2} \mathrm{~S}_{3}$ pattern was matched to the orthorhombic phase JCPDS No. 170320; the peaks at $23.8^{\circ}, 28.28^{\circ}, 31.86^{\circ}, 34.65^{\circ}$, $41.17^{\circ}, 45.52^{\circ}, 47.73^{\circ}, 54.47^{\circ}$, and $58.46^{\circ}$ are related to planes (101), (211), (221), (311), (430), (440), (501), (360), and (640), respectively. The MgO NPS presented by the cubic MgO phase (PDF00-004-0829) with diffraction peaks at $36.95^{\circ}, 42.91^{\circ}, 62.31^{\circ}, 74.69^{\circ}$, and $78.55^{\circ}$ are correlated with planes (111), (200), (220), (311), and (222), respectively, indicate that the precursors of MgO are high levels of crystalline. The typical diffraction peaks of $\mathrm{BiOCl}$ detected in the composite were found in the JCPDS, no. 06-0249 phase. The existence of $\mathrm{BiOCl}$ was confirmed in a previous report, which clarified that the formation of a $\mathrm{BiOCl}$ heterojunction occurs when $\mathrm{Bi}_{2} \mathrm{~S}_{3}$ is mixed with $\mathrm{MgCl}_{2} .6 \mathrm{H}_{2} \mathrm{O}$ precursor in water. The XRD patterns analysis successfully confirmed the easy synthesis of the $\mathrm{MgO} / \mathrm{Bi}_{2} \mathrm{~S}_{3}-\mathrm{BiOCl}$ material for photocatalytic activities.

\subsection{Fourier Transform Infrared Spectroscopy (FTIR) Spectra}

The FTIR analysis in the solid phase was carried out using the $\mathrm{KBr}$ pellet procedure in a $400-4000 \mathrm{~cm}^{-1}$ area to verify the existence of functional groups and the chemical bonding of the materials. Fig. 4 illustrates the FTIR analysis of $\mathrm{MgO}, \mathrm{Bi}_{2} \mathrm{~S}_{3}$, and the $\mathrm{MgO} / \mathrm{Bi}_{2} \mathrm{~S}_{3}-\mathrm{BiOCl}$ material. The prominent peaks at around $528 \mathrm{~cm}^{-1}$ and $1155 \mathrm{~cm}^{-1}$ are related to the $\mathrm{Bi}-\mathrm{O}$ and $\mathrm{Bi}-\mathrm{Cl}$ stretching modes, respectively, implying the presence of highly pure $\mathrm{BiOCl}$ (Seddigi et al., 2017). The vibration at $617 \mathrm{~cm}^{-1}$ is connected to $\mathrm{C}-\mathrm{S}$, and the formation of $\mathrm{Bi}^{3+}$ indicates $\mathrm{C}-\mathrm{N}$ stretching (Jayachandhiran et al., 2017). The vibrational mode centered at $842 \mathrm{~cm}^{-1}$ was attributed to Bi-S stretching (Cao et al., 2018). The regions between $1350 \mathrm{~cm}^{-1}$ to $1450 \mathrm{~cm}^{-1}$ may have been responsible for the Bi-S vibration. The band at $1382 \mathrm{~cm}^{-1}$ was caused by the bending vibration of Mg-O (Essien et al., 2020; Viswanatha et al., 2012), and the vibration at around $3400 \mathrm{~cm}^{-1}$ corresponded to the $\mathrm{O}-\mathrm{H}$ vibration from the water used in the preparation of the material (Zhao et al., 2018). The wavelength at $3421 \mathrm{~cm}^{-1}$ was associated with the $\mathrm{O}-\mathrm{H}$ vibration in alcohol (Dobrucka, 2018; Essien et al., 2020). The band at $3699 \mathrm{~cm}^{-1}$ was due to the formation of $\mathrm{MgO}$

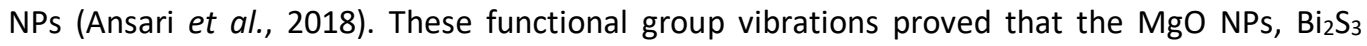
nanorods, and $\mathrm{MgO} / \mathrm{Bi}_{2} \mathrm{~S}_{3}-\mathrm{BiOCl}$ composite were successfully synthesized. The FTIR results also confirmed the formation of $\mathrm{BiOCl}$, which was also observed in the XRD analysis spectra. 


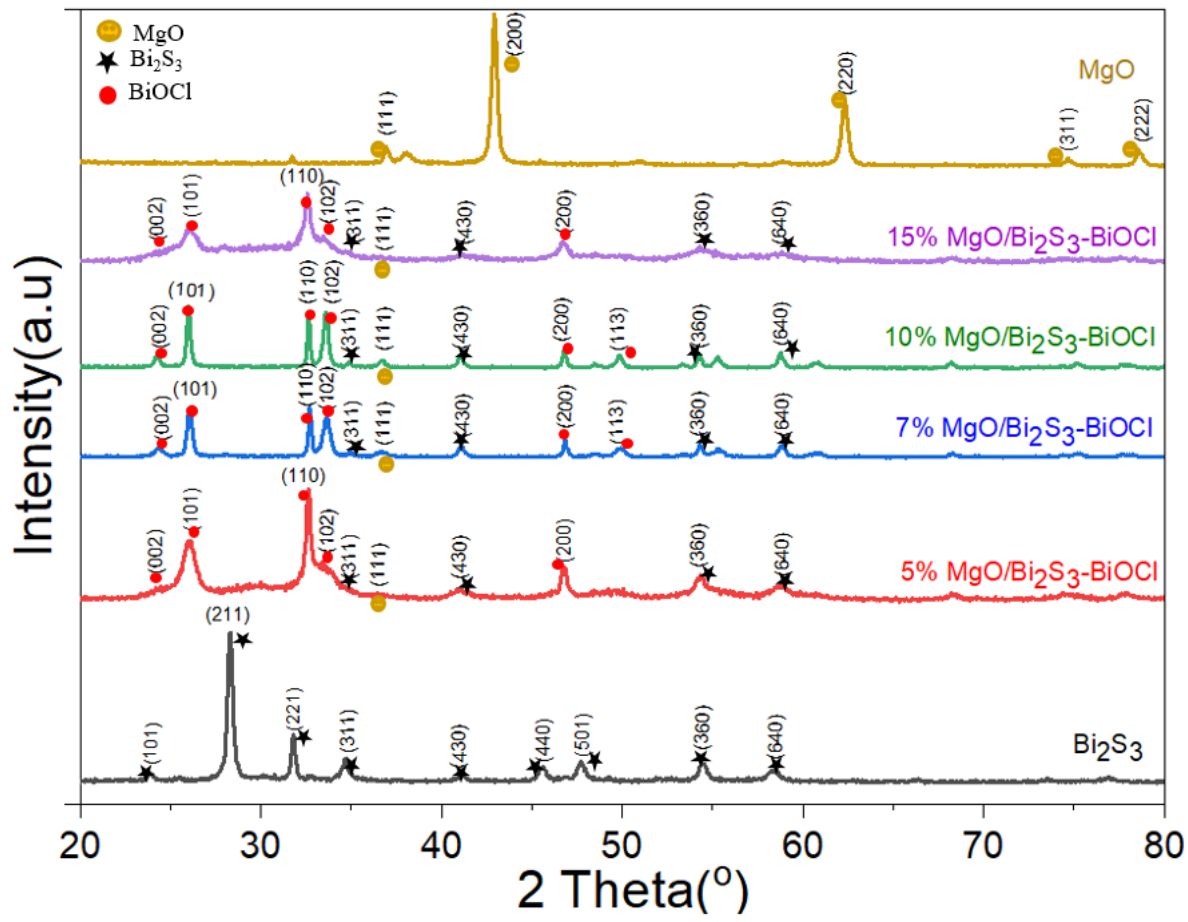

Fig. 3. XRD pattern analysis of the $\mathrm{MgO}, \mathrm{Bi}_{2} \mathrm{~S}_{3}$, and $\mathrm{MgO} / \mathrm{Bi}_{2} \mathrm{~S}_{3}-\mathrm{BiOCl}$ materials.

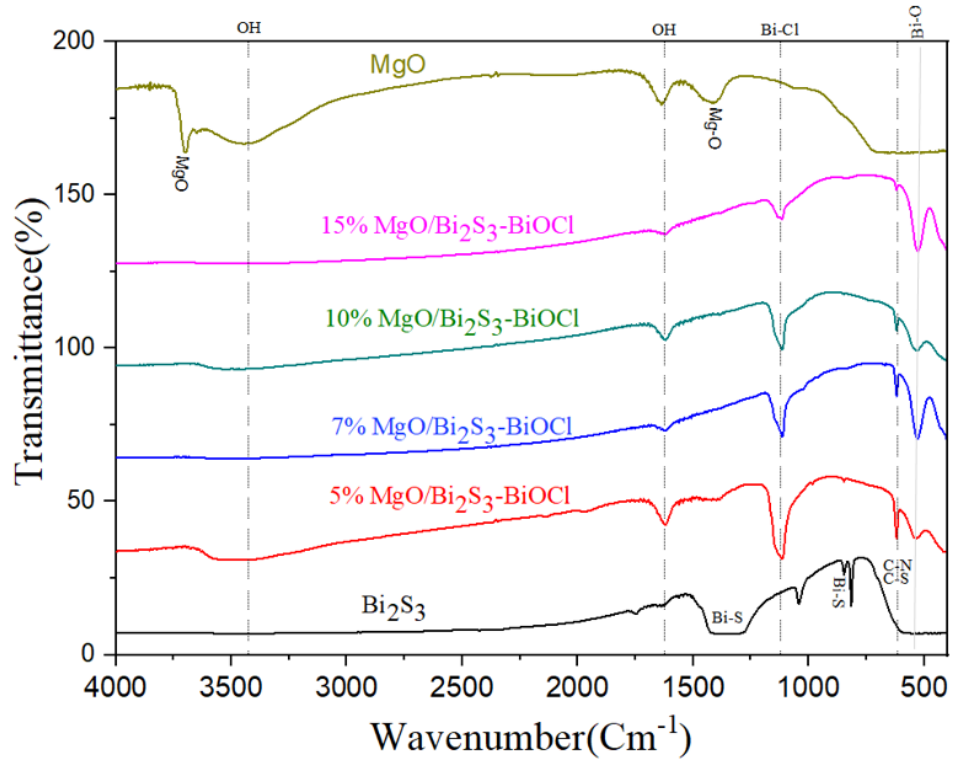

Fig. 4. $\mathrm{FTIR}$ analysis of $\mathrm{Bi}_{2} \mathrm{~S}_{3}, \mathrm{MgO}$, and $\mathrm{MgO} / \mathrm{Bi}_{2} \mathrm{~S}_{3}-\mathrm{BiOCl}$.

\subsection{The Morphology of $\mathrm{MgO} / \mathrm{Bi}_{2} \mathrm{~S}_{3}-\mathrm{BiOCl}$}

The surface morphology of the $\mathrm{Bi}_{2} \mathrm{~S}_{3}, \mathrm{MgO}$, and $\mathrm{MgO} / \mathrm{Bi}_{2} \mathrm{~S}_{3}-\mathrm{BiOCl}$ composites was examined using scanning electron microscopy (SEM). As shown in Figs. 5 (a) and 5(b), the particle sizes of the $\mathrm{Bi}_{2} \mathrm{~S}_{3}$ and $\mathrm{MgO}$ samples are irregular. Figs. $5\left(\mathrm{c}-\mathrm{f}\right.$ ) show that the $\mathrm{MgO} / \mathrm{Bi}_{2} \mathrm{~S}_{3}-\mathrm{BiOCl}$ material at a $5 \%, 7 \%, 10 \%$, and $15 \%$ weight of $\mathrm{MgO}$, respectively, are smoother and could thus provide a better performance in the photocatalytic process. The increase in the MgO content on the surface of $\mathrm{Bi}_{2} \mathrm{~S}_{3}$ indicated the growth of particles in the form of a branched structure, which may have been due to the growth of $\mathrm{MgO}$ nanoparticles over the surface of the $\mathrm{Bi}_{2} \mathrm{~S}_{3}$ leading a more active species that served to catch the photo-induced electrons. Otherwise, the excess amount of $\mathrm{MgO}$ content converted the pores of the catalyst, so the defects became recombination centers 

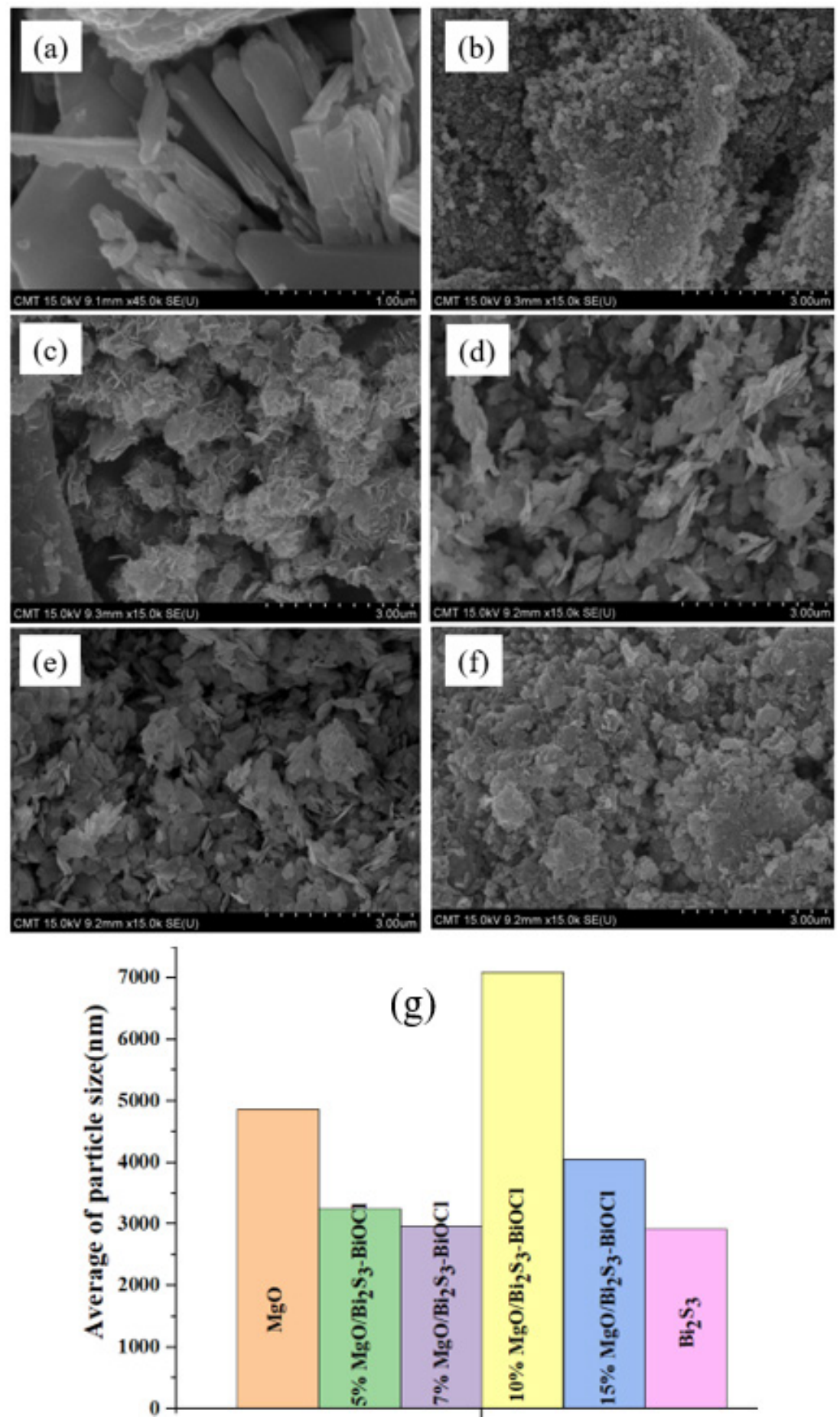

Fig. 5. Scanning electron microscopy image of (a) $\mathrm{Bi}_{2} \mathrm{~S}_{3}$, (b) $\mathrm{MgO}$, (c) $5 \% \mathrm{MgO} / \mathrm{Bi}_{2} \mathrm{~S}_{3}-\mathrm{BiOCl}$, (d) $7 \%$ $\mathrm{MgO} / \mathrm{Bi}_{2} \mathrm{~S}_{3}-\mathrm{BiOCl}$, (e) $10 \% \mathrm{MgO} / \mathrm{Bi}_{2} \mathrm{~S}_{3}-\mathrm{BiOCl}$, and (f) $15 \% \mathrm{MgO} / \mathrm{Bi}_{2} \mathrm{~S}_{3}-\mathrm{BiOCl}$ composites (g) average particle size.

and reduced the photodegradation ability of the composite. The particle size of the material was also measured using Malvern Panalytical's Zetasizer Nano ZS to study the influence of particle size on the photocatalytic degradation of NO. The results shown in Fig. $5(\mathrm{~g})$ indicate that the average particle sizes of $\mathrm{Bi}_{2} \mathrm{~S}_{3}, \mathrm{MgO}, 5 \% \mathrm{MgO}, 7 \% \mathrm{MgO}, 10 \% \mathrm{MgO}$, and 15\% $\mathrm{MgO}$ were $2927 \mathrm{~nm}$, $4871 \mathrm{~nm}, 3251 \mathrm{~nm}, 2963 \mathrm{~nm}, 7093 \mathrm{~nm}$, and $4046 \mathrm{~nm}$, respectively. The formation of BiOCl could have cause the increase in the particle size of the material (Bárdos et al., 2021). Fig. 6(a) presents the transition electron microscopy (TEM) morphology of $\mathrm{Bi}_{2} \mathrm{~S}_{3}$ nanorods synthesized using a 

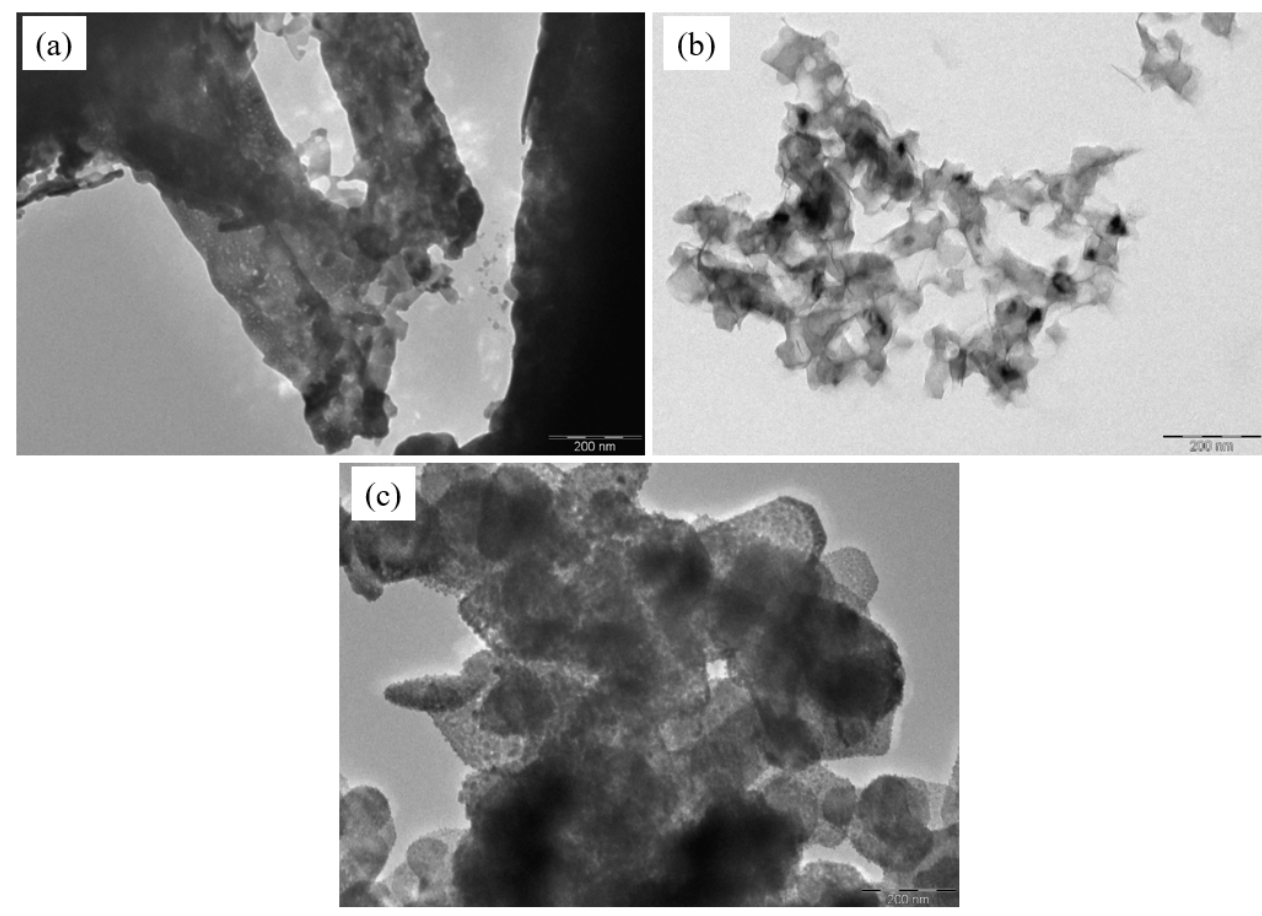

Fig. 6. Transition electron microscopy (TEM) morphology of $\mathrm{Bi}_{2} \mathrm{~S}_{3}, \mathrm{MgO}$, and $7 \% \mathrm{MgO} / \mathrm{Bi}_{2} \mathrm{~S}_{3}-\mathrm{BiOCl}$.

simple precipitation method. The MgO NPs are shown in Fig. 6(b), where the nanoparticles in the image are uniform in size. Fig. 6(c) shows that the morphology of the composite preparation with the doping of the $\mathrm{MgCl}_{2} .6 \mathrm{H}_{2} \mathrm{O}$ precursor on the $\mathrm{Bi}_{2} \mathrm{~S}_{3}$ solution is very different compared to the pure $\mathrm{MgO}$ and $\mathrm{Bi}_{2} \mathrm{~S}_{3}$, which confirmed the formation of the new composite $\mathrm{MgO} / \mathrm{Bi}_{2} \mathrm{~S}_{3}-\mathrm{BiOCl}$ detected in the XRD pattern. Therefore, the characterization of the as-prepared material successfully confirmed the synthesis of the $\mathrm{MgO} / \mathrm{Bi}_{2} \mathrm{~S}_{3}-\mathrm{BiOCl}$ composites using the simple co-precipitation method proposed in this work.

\subsection{Diffuse Reflectance Spectroscopy (DRS) Analysis}

The diffuse reflection spectra (DRS) were used to examine the light absorption behavior of the material at wavelengths ranging between approximately 250 and $800 \mathrm{~nm}$ (Fig. 7). The MgO material exhibits a large wavelength of around $300 \mathrm{~nm}$, which means it can only work under UV light. The $\mathrm{Bi}_{2} \mathrm{~S}_{3}$ materials showed the full wavelength of $800 \mathrm{~nm}$, which could be applied easily

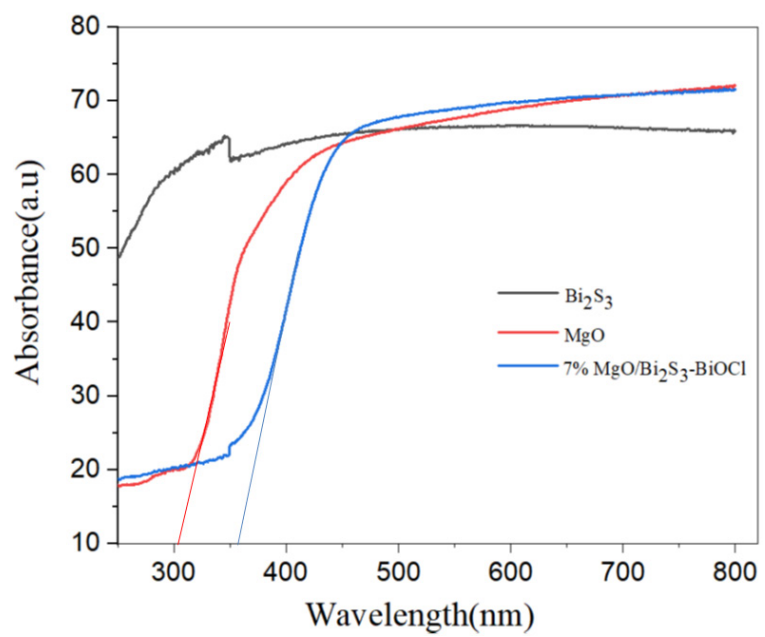

Fig. 7. Diffuse reflectance spectroscopy analysis of $\mathrm{Bi}_{2} \mathrm{~S}_{3}, \mathrm{MgO}$, and $\mathrm{MgO} / \mathrm{Bi}_{2} \mathrm{~S}_{3}-\mathrm{BiOCl}$. 
using visible light. In the case of the $\mathrm{MgO} / \mathrm{Bi}_{2} \mathrm{~S}_{3}-\mathrm{BiOCl}$ material, as a result of the $\mathrm{Bi}_{2} \mathrm{~S}_{3}$ and $\mathrm{MgO}$ in the synthesis process, a wavelength of approximately $350 \mathrm{~nm}$ appeared between the visible light and UV-light area, so the DRS analysis confirmed that this composite can exhibit better performance under solar light than the pure $\mathrm{Bi}_{2} \mathrm{~S}_{3}$ and $\mathrm{MgO}$.

\section{5 $\mathrm{NO}$ degradation Using $\mathrm{MgO}, \mathrm{Bi}_{2} \mathrm{~S}_{3}$, and $\mathrm{MgO} / \mathrm{Bi}_{2} \mathrm{~S}_{3}-\mathrm{BiOCl}$ under Solar Light Irradiation}

Fig. 8(a) shows the photocatalytic performance of $\mathrm{Bi}_{2} \mathrm{~S}_{3}, \mathrm{MgO}$, and $\mathrm{MgO} / \mathrm{Bi}_{2} \mathrm{~S}_{3}-\mathrm{BiOCl}$ for a 30 minute period under solar light irradiation. The $\mathrm{NO}$ degradation efficiency of $\mathrm{Bi}_{2} \mathrm{~S}_{3}, \mathrm{MgO}, 5 \%$ $\mathrm{MgO} / \mathrm{Bi}_{2} \mathrm{~S}_{3}-\mathrm{BiOCl}, 7 \% \mathrm{MgO} / \mathrm{Bi}_{2} \mathrm{~S}_{3}-\mathrm{BiOCl}, 10 \% \mathrm{MgO} / \mathrm{Bi}_{2} \mathrm{~S}_{3}-\mathrm{BiOCl}$, and $15 \% \mathrm{MgO} / \mathrm{Bi}_{2} \mathrm{~S}_{3}-\mathrm{BiOCl}$ were $42.8 \%, 11.2 \%, 66.4 \%, 74.6 \%, 58 \%$, and $50.3 \%$ respectively. The results showed that increasing the amount of $\mathrm{MgO}$ doped on $\mathrm{Bi}_{2} \mathrm{~S}_{3}$ from $5 \%$ to $7 \%$ increased the removal of $\mathrm{NO}$, but the performance of the composite was decreased with increases in the amount of $\mathrm{MgO}$ of more than $7 \%$ because an excessive amount of $\mathrm{MgO}$ can turn the composite to the UV area. However, solar light has less than a 5\% UV irradiation, so the excess amount of pure MgO had poor performance under solar light. In addition, when the amount of $\mathrm{MgO}$ was optimal or less than optimal, the $\mathrm{MgO}$ acted as a photo-induced electron capture center. However, When the weight of the MgO was greater than its maximum value, the reabsorption of photo-induced $\mathrm{e}^{-}$and $\mathrm{h}^{+}$in the material
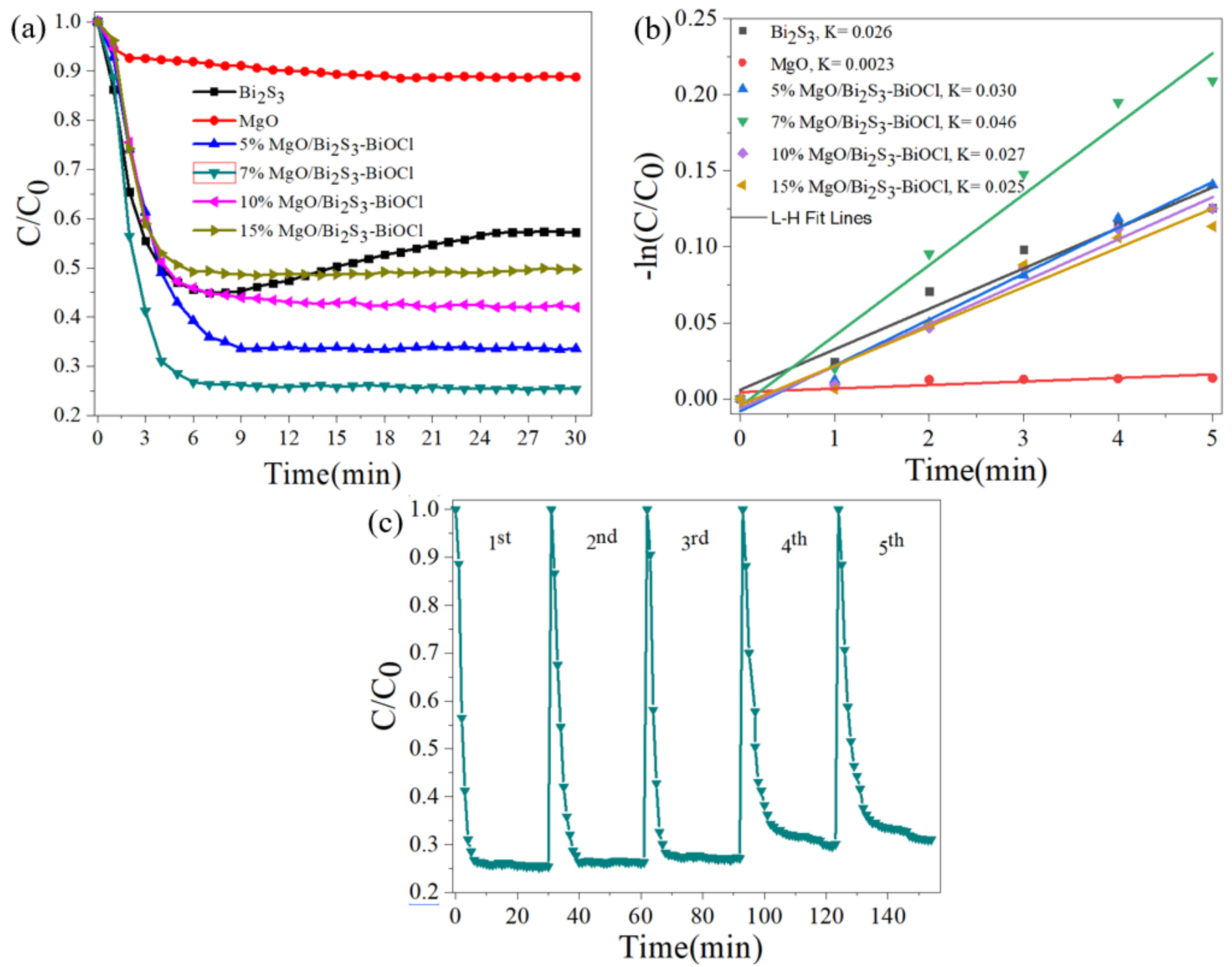

Fig. 8. Nitrogen oxide degradation by $\mathrm{MgO}, \mathrm{Bi}_{2} \mathrm{~S}_{3}$ and $\mathrm{MgO} / \mathrm{Bi}_{2} \mathrm{~S}_{3}-\mathrm{BiOCl}$ under (a) solar light irradiation, (b) $\mathrm{L}-\mathrm{H}$ fit $\mathrm{Lines}$, and reusability test of (c) $7 \% \mathrm{MgO} / \mathrm{Bi}_{2} \mathrm{~S}_{3}-\mathrm{BiOCl}$. 
Table 1. Comparison of previous studies on the photocatalytic degradation of NO.

\begin{tabular}{|c|c|c|c|c|}
\hline Catalysts & NO Concentration(ppb) & Light sources & Removal efficiency (\%) & References \\
\hline $\mathrm{TiO}_{2}$ /graphene & 1000 & UV light & 52.28 & (Trapalis et al., 2016) \\
\hline $\mathrm{SnO}_{2}$ & 500 & Solar light & 63.37 & (Huy et al.,2018) \\
\hline $\mathrm{TiO}_{2}$ /graphene & 1000 & Visible light & 24.05 & (Trapalis et al., 2016) \\
\hline $\mathrm{Ag} / \mathrm{LDH}$ & 400 & Solar light & 43 & (Zhu et al., 2017) \\
\hline $\mathrm{Cr} / \mathrm{ZnO}$ & 500 & Visible light & 24.44 & (Nguyen et al., 2019) \\
\hline $\mathrm{La} / \mathrm{TiO}_{2}$ & 500 & Solar light & 32 & (Huang et al., 2017b) \\
\hline $\mathrm{Pd} / \mathrm{F}-\mathrm{TiO}_{2}$ & 1000 & Solar light & 52 & (Fujiwara et al., 2016) \\
\hline $\mathrm{Bi} / \mathrm{BiOl} /(\mathrm{BiO})_{2} \mathrm{CO}_{3}$ & 550 & Visible light & 50.7 & (Sun et al., 2019) \\
\hline $\mathrm{Ag} @ \mathrm{Bi}_{2} \mathrm{~S}_{3}$ & 500 & Solar light & 31.12 & (Pham et al., 2021) \\
\hline$w-\mathrm{Pd} / \mathrm{c}-\mathrm{TiO}_{2}$ & 1000 & Solar light & 55 & (Fujiwara et al., 2016) \\
\hline $\mathrm{B}, \mathrm{N}$-doped $\mathrm{TiO}_{2}$ & 400 & Visible light & 53 & (Ding et al., 2011) \\
\hline $\mathrm{f}-\mathrm{Pd} / \mathrm{TiO}_{2}$ & 1000 & Solar light & 63.5 & (Fujiwara et al., 2016) \\
\hline $\mathrm{SnO}_{2} / \mathrm{PANI}$ & 450 & Solar light & 16 & (Bui et al., 2018) \\
\hline $\mathrm{MgO} / \mathrm{Bi}_{2} \mathrm{~S}_{3}-\mathrm{BiOCl}$ & 500 & Solar light & 74.61 & This study \\
\hline
\end{tabular}

increased and led to poor degradation of the pollutant (Guo et al., 2012). In addition, the average particle size of the composite material showed that the $7 \% \mathrm{MgO} / \mathrm{Bi}_{2} \mathrm{~S}_{3}-\mathrm{BiOCl}$ had the lowest particle size, which led to an increase the surface area available for producing more active species and in turn, to better degradation of NO under solar light. A comparison with some previous publications is provided in Table 1, which shows that the photodegradation of nitrogen oxide is limited under visible light, solar light, and even UV light. Therefore, in the present study, the new, efficient $\mathrm{MgO} / \mathrm{Bi}_{2} \mathrm{~S}_{3}-\mathrm{BiOCl}$ composites applied for the first time for photocatalytic degradation of nitrogen oxide, showed significant results under solar light. The comparison also shows that the $\mathrm{MgO} / \mathrm{Bi}_{2} \mathrm{~S}_{3}-\mathrm{BiOCl}$ composites for degradation of $\mathrm{NO}$ are very competitive and may be candidates for practical application. The Fig. $8(\mathrm{~b})$ indicated that the reaction rates (k) of the $\mathrm{Bi}_{2} \mathrm{~S}_{3}, \mathrm{MgO}, 5 \%$ $\mathrm{MgO} / \mathrm{Bi}_{2} \mathrm{~S}_{3}-\mathrm{BiOCl}, 7 \% \mathrm{MgO} / \mathrm{Bi}_{2} \mathrm{~S}_{3}-\mathrm{BiOCl}, 10 \% \mathrm{MgO} / \mathrm{Bi}_{2} \mathrm{~S}_{3}-\mathrm{BiOCl}$, and $15 \% \mathrm{MgO} / \mathrm{Bi}_{2} \mathrm{~S}_{3}-\mathrm{BiOCl}$ were $0.026,0.0023,0.030,0.046,0.027$, and 0.025 , respectively, which indicates that the $7 \% \mathrm{MgO} / \mathrm{Bi}_{2} \mathrm{~S}_{3}-$ $\mathrm{BiOCl}$ exhibited the highest degradation rate. Furthermore, due to the method used to synthesize $\mathrm{MgO} / \mathrm{Bi}_{2} \mathrm{~S}_{3}-\mathrm{BiOCl}$, the components at the $\mathrm{BiOCl}$ heterojunction could not be separates from the composite to measure their individual performance in the photodegradation activities of NO. The stability of the photocatalyst, as shown in Fig. 8(c), was studied to evaluate the reusability of using the $7 \% \mathrm{MgO} / \mathrm{Bi}_{2} \mathrm{~S}_{3}-\mathrm{BiOCl}$ material. The result showed that the photocatalytic degradation of NO remained stable after five cycles, implying that the photocatalyst was highly stable throughout the photodegradation process.

\subsection{Trapping Test, DMPO-ESR Spectra, and Photodegradation Mechanism of $\mathrm{NO}$ Using $\mathrm{MgO} / \mathrm{Bi}_{2} \mathrm{~S}_{3}-\mathrm{BiOCl}$ under Solar Light}

The trapping experiment was conducted to determine the main active factor contributing to the photodegradation of nitrogen oxide using $\mathrm{MgO} / \mathrm{Bi}_{2} \mathrm{~S}_{3}-\mathrm{BiOCl}$ by confirming its photocatalytic mechanism under solar light. Fig. 9(a) shows that the removal efficiency of NO was slightly decreased by the addition of $10^{-3} \mathrm{M}$ of potassium dichromate $\left(\mathrm{K}_{2} \mathrm{Cr}_{2} \mathrm{O}_{7}\right.$ ) (a quencher of $\cdot \mathrm{O}_{2}^{-}$), but significantly decreased by adding isopropanol (IPA) (a quencher of ${ }^{\circ} \mathrm{OH}$ ) and potassium iodide (KI) (a quencher of $h^{+}$). Therefore, the results show that the $\mathrm{h}^{+}$and $\mathrm{OH}$ radicals of the $\mathrm{MgO} / \mathrm{Bi}_{2} \mathrm{~S}_{3}-$ $\mathrm{BiOCl}$ composite are the main factors contributing to the photodegradation of NO under solar light.

To understand the potential of the production of reactive oxygen species, the trapping test was conducted using electron spin resonance of a $7 \% \mathrm{MgO} / \mathrm{Bi}_{2} \mathrm{~S}_{3}-\mathrm{BiOCl}$ material for 12 minutes with 5,5-Dimethyl-1-Pyrroline N-oxide (DMPO-ESR) (ROS). The results in Fig. 9(b) reveal that under dark conditions, there is almost no signal for (DMPO-•OH), and $\left(\mathrm{DMPO}^{-} \mathrm{O}_{2}{ }^{-}\right)$. After the light was turned on, active vibration was detected. The results explain that the generated $\mathrm{OH}$ radicals came from the holes $\left(\mathrm{h}^{+}\right)$and facilitated the oxidation of nitrogen oxide.

The mechanism of the degradation of $\mathrm{NO}$ by $\mathrm{MgO} / \mathrm{Bi}_{2} \mathrm{~S}_{3}-\mathrm{BiOCl}$ under solar light can be described by the following reactions: Eq. (1) explains that the holes stay in the valence band (VB), and the 

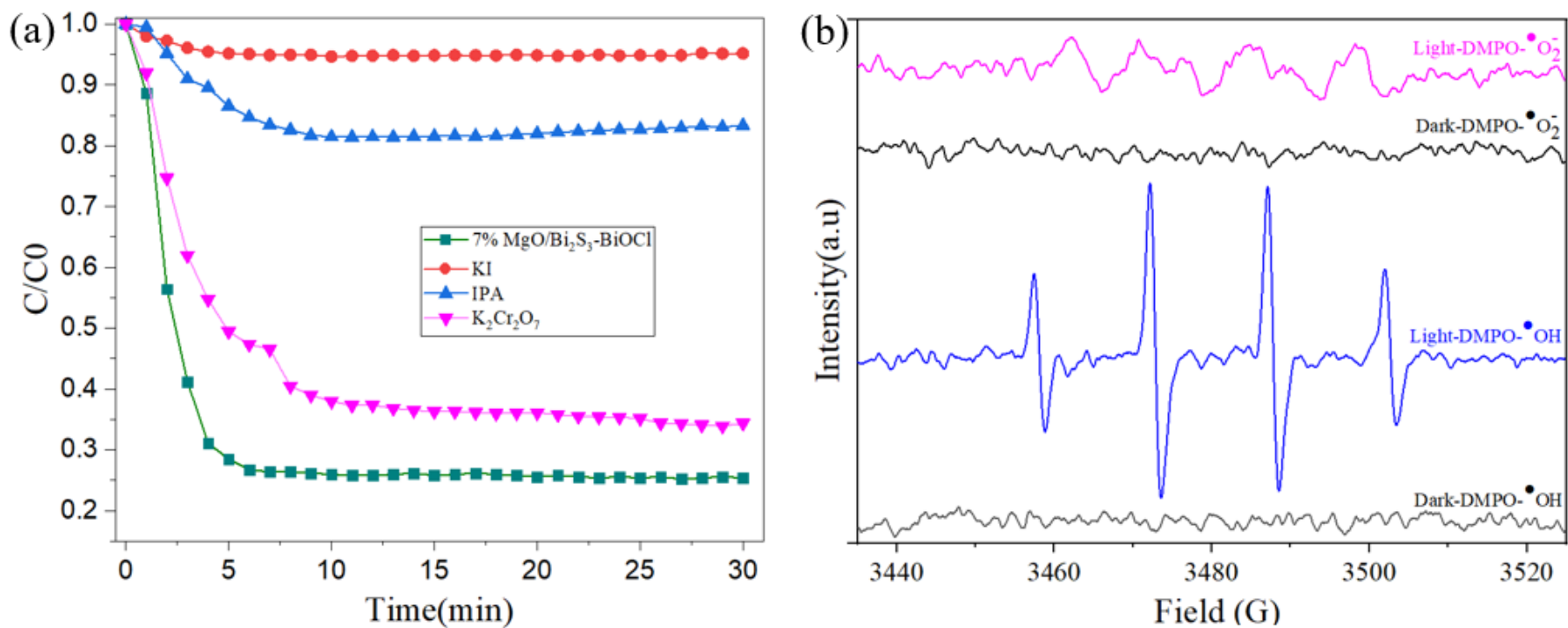

Fig. 9. (a) Active species trapping test, (b) DMPO-ESR spectra of $7 \% \mathrm{MgO} / \mathrm{Bi}_{2} \mathrm{~S}_{3}-\mathrm{BiOCl}$.

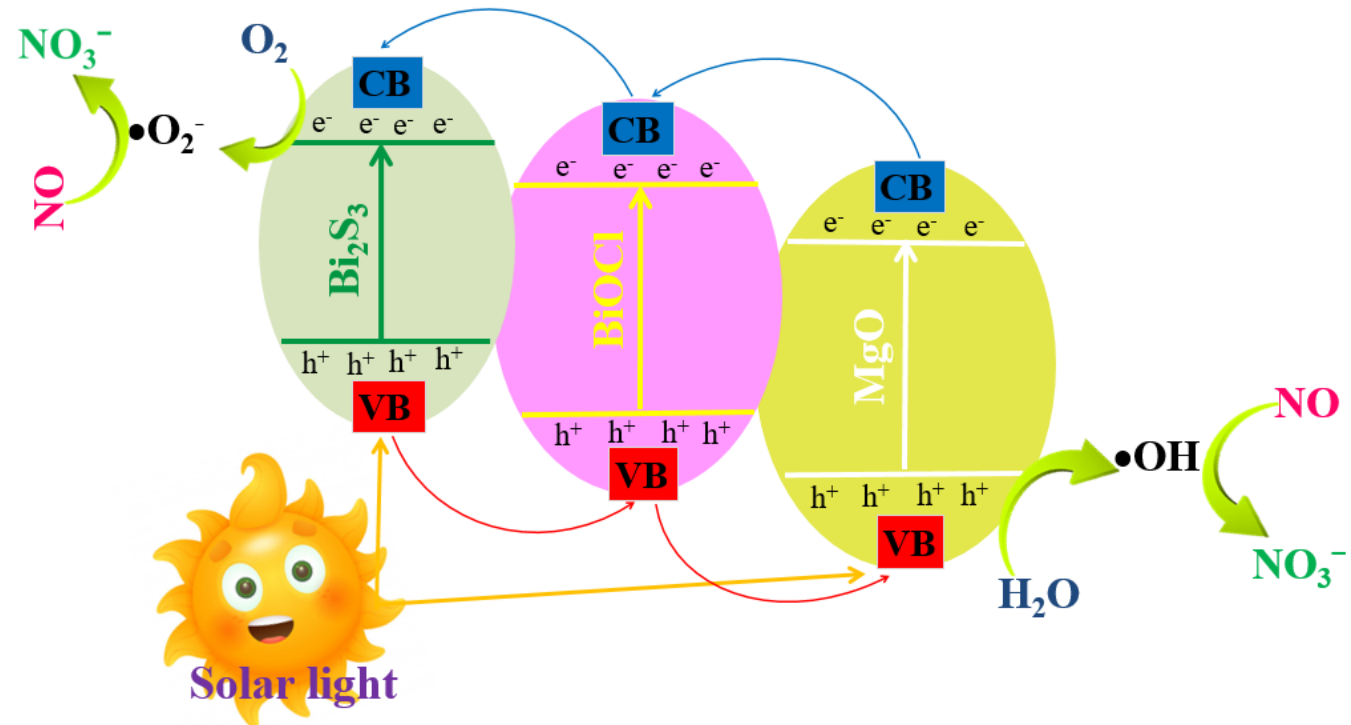

Fig. 10. Mechanism of $\mathrm{NO}$ photocatalytic degradation using $\mathrm{MgO} / \mathrm{Bi}_{2} \mathrm{~S}_{3}-\mathrm{BiOCl}$.

excited electrons move from the valence band (VB) to the conduction band (CB). The electron-hole couples travel to the surface of the $\mathrm{MgO} / \mathrm{Bi}_{2} \mathrm{~S}_{3}-\mathrm{BiOCl}$. Eq. (2) explains that the electrons then combine with oxygen to form ${ }^{\circ} \mathrm{O}_{2}$. In Eq. (5), ${ }^{\circ} \mathrm{OH}$ forms by the combination of holes $\left(\mathrm{h}^{+}\right)$with the $\mathrm{OH}^{-}$from Eqs. (3) and (4). In Eq. (6), ${ }^{\circ} \mathrm{OH}$ forms when the holes react with water.

In terms of Eqs. (7) and (9), Fig. 10 shows that both $\cdot \mathrm{O}_{2}{ }^{-}$and $\bullet \mathrm{OH}$ reacted and degraded $\mathrm{NO}$ into $\mathrm{NO}_{3}$, and the ESR spectra and the trapping analysis shown in Fig. 9 explain that $\cdot \mathrm{O}_{2}{ }^{-}$and $\bullet \mathrm{OH}$ are used for the photocatalytic degradation of NO under solar light.

$$
\begin{aligned}
& \mathrm{MgO} / \mathrm{Bi}_{2} \mathrm{~S}_{3}-\mathrm{BiOCl}+\mathrm{hv} \rightarrow \mathrm{MgO} / \mathrm{Bi}_{2} \mathrm{~S}_{3}-\mathrm{BiOCl}\left(\mathrm{h}^{+} \mathrm{VB}+\mathrm{e}^{-} \mathrm{CB}\right) \\
& \mathrm{O}_{2}+\mathrm{e}^{-} \mathrm{CB} \rightarrow \cdot \mathrm{O}^{-} \\
& \mathrm{H}_{2} \mathrm{O}+\cdot \mathrm{O}_{2}^{-}+\rightarrow \mathrm{OH}^{-}+\cdot \mathrm{HO}_{2} \\
& \cdot \mathrm{HO}_{2}+\mathrm{H}_{2} \mathrm{O}+\mathrm{e}^{-} \rightarrow \mathrm{H}_{2} \mathrm{O}_{2}+\mathrm{OH}^{-}
\end{aligned}
$$




$$
\begin{aligned}
& \mathrm{h}^{+}+\mathrm{OH}^{-} \rightarrow \cdot \mathrm{OH} \\
& \mathrm{H}_{2} \mathrm{O}+\mathrm{h}^{+} \rightarrow \mathrm{HO} \cdot+\mathrm{H}^{+} \\
& \mathrm{NO}+\cdot \mathrm{O}_{2}^{-} \rightarrow \mathrm{NO}_{3}^{-} \\
& \mathrm{NO}+2 \mathrm{HO} \cdot \rightarrow \mathrm{NO}_{2}+\mathrm{H}_{2} \mathrm{O} \\
& \mathrm{NO}_{2}+\cdot \mathrm{OH} \rightarrow \mathrm{NO}_{3}^{-}+\mathrm{H}^{+}
\end{aligned}
$$

\section{CONCLUSIONS}

This research was focused on introducing a new, efficient photocatalyst $\left(\mathrm{MgO} / \mathrm{Bi}_{2} \mathrm{~S}_{3}-\mathrm{BiOCl}\right)$ for the purpose of reducing the fast recombination of electron-hole pairs during the degradation of nitrogen oxide under solar light.

The surfaces analysis confirmed that the $\mathrm{MgO} / \mathrm{Bi}_{2} \mathrm{~S}_{3}-\mathrm{BiOCl}$ composite was successfully synthesized using the easy method proposed in this work.

The results showed that only $7 \% \mathrm{MgO}$ was doped on $\mathrm{Bi}_{2} \mathrm{~S}_{3}$, which indicates optimum removal efficiency and a higher degradation rate. Furthermore, the $7 \% \mathrm{MgO} / \mathrm{Bi}_{2} \mathrm{~S}_{3}-\mathrm{BiOCl}$ composite also had the smallest particle size, which contributed to increasing the surface area of the composite and leading to better degradation of NO.

The formation of $\mathrm{BiOCl}$ in the composite improved the active species and led to better photodegradation of NO under solar light irradiation. The photodegradation efficiency of NO with the application of $7 \% \mathrm{MgO} / \mathrm{Bi}_{2} \mathrm{~S}_{3}-\mathrm{BiOCl}$ was around 1.75 times higher than was the case for the pure $\mathrm{Bi}_{2} \mathrm{~S}_{3}$.

The trapping test and DMPO-ESR spectra showed that the holes $\left(\mathrm{h}^{+}\right)$and the $\mathrm{OH}$ radicals were the main factors contributing to the photodegradation of NO when solar light was applied to the compound of $7 \% \mathrm{MgO} / \mathrm{Bi}_{2} \mathrm{~S}_{3}-\mathrm{BiOCl}$.

The photocatalytic degradation results also showed that the pure $\mathrm{Bi}_{2} \mathrm{~S}_{3}$ was unstable during the degradation process, and the presence of the $\mathrm{MgO}$ doped on the $\mathrm{Bi}_{2} \mathrm{~S}_{3}$ led to good stability even after five recycles.

Additionally, the $\mathrm{MgO} / \mathrm{Bi}_{2} \mathrm{~S}_{3}-\mathrm{BiOCl}$ composite is very competitive compared to the degradation of $\mathrm{NO}$ in the previous studies. Finally, the use of precursors that contain $\mathrm{Cl}$ ion are suggested to improve the performance of $\mathrm{Bi}_{2} \mathrm{~S}_{3}$ by promoting more active species in the photodegradation of environmental pollutants for practical applications.

\section{ACKNOWLEDGEMENT}

A special thanks to Chung Yuan Christian University for supporting this work through project number: 109609432.

\section{DSICLAIMER}

This present manuscript has no financial interests in completing

\section{REFERENCES}

Ansari, A., Ali, A., Asif, M., Shamsuzzaman, S. (2018). Microwave-assisted MgO NP catalyzed onepot multicomponent synthesis of polysubstituted steroidal pyridines. New J. Chem. 42, 184197. https://doi.org/10.1039/C7NJ03742B

Bao, H., Li, C.M., Cui, X., Gan, Y., Song, Q., Guo, J. (2008). Synthesis of a highly ordered singlecrystalline $\mathrm{Bi}_{2} \mathrm{~S}_{3}$ nanowire array and its metal/semiconductor/metal back-to-back schottky diode. Small 4, 1125-1129. https://doi.org/10.1002/smll.200800007

Bárdos, E., Márta, V.A., Fodor, S., Kedves, E.Z., Hernadi, K., Pap, Z. (2021). Hydrothermal 
crystallization of bismuth oxychlorides $(\mathrm{BiOCl})$ using different shape control reagents. Materials 14, 2261. https://doi.org/10.3390/ma14092261

Biswas, M.S., Mahajan, A.S. (2021). Year-long concurrent MAX-DOAS observations of nitrogen dioxide and formaldehyde at pune: Understanding diurnal and seasonal variation drivers. Aerosol Air Qual. Res. 21, 200524. https://doi.org/10.4209/aaqr.200524

Biswas, M.S., Pandithurai, G., Aslam, M.Y., Patil, R.D., Anilkumar, V., Dudhambe, S.D., Lerot, C., De Smedt, I., Van Roozendael, M., Mahajan, A.S. (2021). Effect of boundary layer evolution on nitrogen dioxide $\left(\mathrm{NO}_{2}\right)$ and formaldehyde $(\mathrm{HCHO})$ concentrations at a high-altitude observatory in western India. Aerosol Air Qual. Res. 21, 200193. https://doi.org/10.4209/aaqr.2020.05.0193

Bui, P.D., Tran, H.H., Kang, F., Wang, Y.F., Cao, T.M., You, S.J., Vu, N.H., Pham, V.V. (2018). Insight into the photocatalytic mechanism of tin dioxide/polyaniline nanocomposites for NO degradation under solar light. ACS Appl. Nano Mater. 1, 5786-5794. https://doi.org/10.1021/a csanm.8b01445

Cao, J.T., Wang, B., Dong, Y.X., Wang, Q., Ren, S.W., Liu, Y.M., Zhao, W.W. (2018). Photogenerated hole-induced chemical redox cycling on $\mathrm{Bi}_{2} \mathrm{~S}_{3} / \mathrm{Bi}_{2} \mathrm{Sn}_{2} \mathrm{O}_{7}$ heterojunction: Toward general amplified split-type photoelectrochemical immunoassay. ACS Sens. 3, 1087-1092. https://doi.org/10.1021/acssensors.8b00332

Chen, L., Zheng, C., Gao, X., Cen, K., Bao, K., Li, K., Lv, B., Bao, Z., Lin, C., Wu, X. (2017). Ozone and secondary organic aerosol formation of toluene/ $\mathrm{NO}_{\mathrm{x}}$ irradiations under complex pollution scenarios. Aerosol Air Qual. Res. 17, 1760-1771. https://doi.org/10.4209/aaqr.2017.05.0179

Ding, X., Song, X., Li, P., Ai, Z., Zhang, L. (2011). Efficient visible light driven photocatalytic removal of $\mathrm{NO}$ with aerosol flow synthesized $\mathrm{B}, \mathrm{N}$-codoped $\mathrm{TiO}_{2}$ hollow spheres. J. Hazard. Mater. 190, 604-612. https://doi.org/10.1016/j.jhazmat.2011.03.099

Dobrucka, R. (2018). Synthesis of MgO nanoparticles using artemisia abrotanum herba extract and their antioxidant and photocatalytic properties. Iran J. Sci. Tchnol. A 42, 547-555. https://doi.org/10.1007/s40995-016-0076-x

Essien, E.R., Atasie, V.N., Okeafor, A.O., Nwude, D.O. (2020). Biogenic synthesis of magnesium oxide nanoparticles using Manihot esculenta (Crantz) leaf extract. Int. Nano Lett. 10, 43-48. https://doi.org/10.1007/s40089-019-00290-w

Fenelon, E., Bui, D.P., Tran, H.H., You, S.J., Wang, Y.F., Cao, T.M., Van Pham, V. (2020). Straightforward Synthesis of $\mathrm{SnO}_{2} / \mathrm{Bi}_{2} \mathrm{~S}_{3} / \mathrm{BiOCl}-\mathrm{Bi}_{24} \mathrm{O}_{31} \mathrm{Cl}_{10}$ composites for drastically enhancing rhodamine B photocatalytic degradation under visible light. ACS Omega 5, 20438-20449. https://doi.org/10.1021/acsomega.0c02461

Fenelon, E., Hussain, A., Yang, T.H., Chang, G.M., Chen, S.W., Wei, R.J., You, S.J., Wang, Y.F. (2019). High photocatalyst module on degradation of extracted gas from soil under visible light. Aerosol Air Qual. Res. 19, 2865-2878. https://doi.org/10.4209/aaqr.2019.10.0499

Feng, H., Xu, H., Feng, H., Gao, Y., Jin, X. (2019). The sol-gel synthesis and photocatalytic activity of $\mathrm{Gd}-\mathrm{SiO}_{2}-\mathrm{TiO}_{2}$ photocatalyst. Chem. Phys. Lett. 733, 136676. https://doi.org/10.1016/j.cplett. 2019.136676

Fujiwara, K., Müller, U., Pratsinis, S.E. (2016). Pd subnano-clusters on $\mathrm{TiO}_{2}$ for solar-light removal of NO. ACS Catal. 6, 1887-1893. https://doi.org/10.1021/acscatal.5b02685

Gao, D.Z., Watkins, M.B., Shluger, A.L. (2012). Transient mobility mechanisms of deposited metal atoms on insulating surfaces: Pd on MgO (100). J. Phys. Chem. C 116, 14471-14479. https://doi.org/10.1021/jp303951y

Guan, M., Xiao, C., Zhang, J., Fan, S., An, R., Cheng, Q., Xie, J., Zhou, M., Ye, B., Xie, Y. (2013). Vacancy Associates promoting solar-driven photocatalytic activity of ultrathin bismuth oxychloride nanosheets. J. Am. Chem. Soc. 135, 10411-10417. https://doi.org/10.1021/ja402956f

Guo, D., Hu, C., Zhang, C. (2013). First-principles study on doping and temperature dependence of thermoelectric property of Bi2S3 thermoelectric material. Mater. Res. Bull. 48, 1984-1988. https://doi.org/10.1016/j.materresbull.2013.02.004

Guo, Y., Zhang, G., Gan, H., Zhang, Y. (2012). Micro/nano-structured CaWO $4 / \mathrm{Bi}_{2} \mathrm{WO}_{6}$ composite: Synthesis, characterization and photocatalytic properties for degradation of organic contaminants. Dalton Trans. 41, 12697-12703. https://doi.org/10.1039/C2DT31376F

Huang, Y., Cao, J.J., Kang, F., You, S.J., Chang, C.W., Wang, Y.F. (2017). High selectivity of visiblelight-driven La-doped $\mathrm{TiO}_{2}$ photocatalysts for NO removal. Aerosol Air Qual. Res. 17, 25552565. https://doi.org/10.4209/aaqr.2017.08.0282 
Huy, T.H., Phat, B., Thi, C.M., Viet, P.V. (2018). High photocatalytic removal of $\mathrm{NO}$ gas over $\mathrm{SnO}_{2}$ nanoparticles under solar light. Environ. Chem. Lett. 17, 527-531. https://doi.org/10.1007/s10 311-018-0801-0

Jayachandhiran, A., Raj, D., Alphonse, A.A. (2017). Solvent effects on the properties of $\mathrm{Bi}_{2} \mathrm{~S}_{3}$ nanoparticles: Photocatalytic application. J. Mater. Sci.: Mater. Electron. 28, 3487-3494. https://doi.org/10.1007/s10854-016-5947-6

John, P., Johari, K., Gnanasundaram, N., Appusamy, A., Thanabalan, M. (2021). Enhanced photocatalytic performance of visible light driven $\mathrm{TiO}_{2} / \mathrm{g}-\mathrm{C}_{3} \mathrm{~N}_{4}$ for degradation of diclofenac in aqueous solution. Environ. Technol. Innovation 22, 101412. https://doi.org/10.1016/j.eti.2021. 101412

Lei, Y., Wang, G., Song, S., Fan, W., Zhang, H. (2009). Synthesis, characterization and assembly of $\mathrm{BiOCl}$ nanostructure and their photocatalytic properties. CrystEngComm. 11, 1857-1862. https://doi.org/10.1039/B909013B

Li, D.B., Hu, L., Xie, Y., Niu, G., Liu, T., Zhou, Y., Gao, L., Yang, B., Tang, J. (2016). Low-temperatureprocessed amorphous $\mathrm{Bi}_{2} \mathrm{~S}_{3}$ film as an inorganic electron transport layer for perovskite solar cells. ACS Photonics 3, 2122-2128. https://doi.org/10.1021/acsphotonics.6b00582

Li, J., Zhang, W., Ran, M., Sun, Y., Huang, H., Dong, F. (2019). Synergistic integration of Bi metal and phosphate defects on hexagonal and monoclinic $\mathrm{BiPO}_{4}$ : Enhanced photocatalysis and reaction mechanism. Appl. Catal. B 243, 313-321. https://doi.org/10.1016/j.apcatb.2018.10.055

$\mathrm{Li}, \mathrm{Y}$., Zhao, H., Wu, Y. (2015). Characteristics of particulate matter during haze and fog (pollution) episodes over northeast China, Autumn 2013. Aerosol and Air Qual. Res. 15, 853-864. https://doi.org/10.4209/aaqr.2014.08.0158

Liu, L., Zheng, C., Qu, R., Wang, J., Liu, X., Wu, W., Gao, X. (2019). Non-thermal plasma assisted preparation of $\mathrm{MnCeO}_{\mathrm{x}}, \mathrm{MnO}_{\mathrm{x}}$ and $\mathrm{CeO}_{2}$ catalysts for enhancement of surface active oxygen and NO oxidation activity. Aerosol Air Qual. Res. 19, 945-958. https://doi.org/10.4209/aaqr.2 018.12.0456

Long, L.L., Zhang, A.Y., Huang, Y.X., Zhang, X., Yu, H.Q. (2015). A robust cocatalyst Pd 4 S uniformly anchored onto $\mathrm{Bi}_{2} \mathrm{~S}_{3}$ nanorods for enhanced visible light photocatalysis. J. Mater. Chem. A 3, 4301-4306. https://doi.org/10.1039/C4TA05818F

Neves, T.M., Frantz, T.S., do Schenque, E.C.C., Gelesky, M.A., Mortola, V.B. (2017). An investigation into an alternative photocatalyst based on $\mathrm{CeO}_{2} / \mathrm{Al}_{2} \mathrm{O}_{3}$ in dye degradation. Environ. Technol. Innovation 8, 349-359. https://doi.org/10.1016/j.eti.2017.08.003

Nguyen, S.N., Truong, T.K., You, S.J., Wang, Y.F., Cao, T.M., Pham, V. V. (2019). Investigation on photocatalytic removal of NO under visible light over $\mathrm{Cr}$-doped $\mathrm{ZnO}$ nanoparticles. ACS Omega 4, 12853-12859. https://doi.org/10.1021/acsomega.9b01628

Nie, G., Lu, X., Lei, J., Yang, L., Wang, C. (2015). Facile and controlled synthesis of bismuth sulfide nanorods-reduced graphene oxide composites with enhanced supercapacitor performance. Electrochim. Acta 154, 24-30. https://doi.org/10.1016/j.electacta.2014.12.090

Pham, M.T., Bui, D.P., Lin, I.F., Phuong, N.H., Huang, Y., Cao, J., You, S.J., Wang, Y.F. (2020). Enhanced near-visible-light photocatalytic removal of formaldehyde over Au-assisted $\mathrm{ZnSn}(\mathrm{OH})_{6}$ microcubes. Environ. Technol. Innovation 20, 101112. https://doi.org/10.1016/j.eti.2020.101112

Pham, M.T., Hussain, A., Bui, D.P., Nguyen, T.M.T., You, S.J., Wang, Y.F. (2021). Surface plasmon resonance enhanced photocatalysis of $\mathrm{Ag}$ nanoparticles-decorated $\mathrm{Bi}_{2} \mathrm{~S}_{3}$ nanorods for $\mathrm{NO}$ degradation. Environ. Technol. Innovation 23, 101755. https://doi.org/10.1016/j.eti.2021.101 755

Seddigi, Z.S., Gondal, M.A., Baig, U., Ahmed, S.A., Abdulaziz, M.A., Danish, E.Y., Khaled, M.M., Lais, A. (2017). Facile synthesis of light harvesting semiconductor bismuth oxychloride nano photo-catalysts for efficient removal of hazardous organic pollutants. PLoS ONE 12, e0172218. https://doi.org/10.1371/journal.pone.0172218

Sun, B., Dong, J., Shi, W.J., Ai, S.Y. (2016). A hierarchical charge transport cascade based on W$\mathrm{Bi}_{2} \mathrm{~S}_{3} /$ poly(thiophenyl-3-boronic acid) hybrid for robust photoelectrochemical analysis of subgroup J of avian leukosis virus. Sens. Actuators, B 229, 75-81. https://doi.org/10.1016/j.sn b.2016.01.063

Sun, Y., Liao, J., Dong, F., Wu, S., Sun, L. (2019). A Bi/BiOI/(BiO) ${ }_{2} \mathrm{CO}_{3}$ heterostructure for enhanced photocatalytic NO removal under visible light. Chinese J. Catal. 40, 362-370. https://doi.org/1 0.1016/S1872-2067(18)63187-0 
Trapalis, A., Todorova, N., Giannakopoulou, T., Boukos, N., Speliotis, T., Dimotikali, D., Yu, J. (2016). $\mathrm{TiO}_{2}$ /graphene composite photocatalysts for $\mathrm{NO}_{x}$ removal: A comparison of surfactantstabilized graphene and reduced graphene oxide. Appl. Catal., B 180, 637-647. https://doi.org/ 10.1016/j.apcatb.2015.07.009

Viswanatha, R., Venkatesh, T., Vidyasagar, C., Nayaka, Y.A. (2012). Preparation and characterization of ZnO and Mg-ZnO nanoparticle. Arch. Appl. Sci. Res. 4, 480-486.

Wang, G., Zhang, R., Gomez, M.E., Yang, L., Levy Zamora, M., Hu, M., Lin, Y., Peng, J., Guo, S., Meng, J., Li, J., Cheng, C., Hu, T., Ren, Y., Wang, Yuesi, Gao, J., Cao, J., An, Z., Zhou, W., Li, G., et al. (2016). Persistent sulfate formation from London Fog to Chinese haze. Proc. Natl. Acad. Sci. U.S.A. 113, 13630-13635. https://doi.org/10.1073/pnas.1616540113

Wang, Q., Zhou, J., Zhang, J., Zhu, H., Feng, Y., Jin, J. (2020). Effect of ceria doping on catalytic activity and $\mathrm{SO}_{2}$ resistance of $\mathrm{MnO}_{x} / \mathrm{TiO}_{2}$ catalysts for selective catalytic reduction of $\mathrm{NO}$ with $\mathrm{NH}_{3}$ at low temperature. Aerosol Air Qual. Res. 20, 477-488. https://doi.org/10.4209/aaqr.20 19.10.0546

Yan, J., Zhou, F., Zhou, Y., Wu, X., Zhu, Q., Liu, H., Lu, H. (2018). Wet oxidation and absorption procedure for $\mathrm{NO}_{x}$ removal. Environ. Technol. Innovation 11, 41-48. https://doi.org/10.1016/j. eti.2018.03.006

Yu, C., Wang, H., Lu, M., Zhu, F., Yang, Y., Huang, H., Zou, C., Xiong, J., Zhong, Z. (2020). Agricultural waste derived catalysts for low temperature SCR process: Optimization of preparation process, catalytic activity and characterization. Aerosol Air Qual. Res. 20, 862-876. https://doi.org/10.4 209/aaqr.2019.11.0596

Zhang, B., Chen, D., Liu, H., Zou, X., Chen, T. (2020). Selective catalytic reduction of NO with $\mathrm{NH}_{3}$ over high purity palygorskite-supported $\mathrm{MnO}_{2}$ with different crystal structures. Aerosol Air Qual. Res. 20, 1155-1165. https://doi.org/10.4209/aaqr.2020.03.0099

Zhang, X., Wang, X.B., Wang, L.W., Wang, W.K., Long, L.L., Li, W.W., Yu, H.Q. (2014). Synthesis of a highly efficient $\mathrm{BiOCl}$ single-crystal nanodisk photocatalyst with exposing $\{001\}$ facets. ACS Appl. Mater. Inter. 6, 7766-7772. https://doi.org/10.1021/am5010392

Zhao, G., Zheng, Y., He, Z., Lu, Z., Wang, L., Li, C., Jiao, F., Deng, C. (2018). Synthesis of $\mathrm{Bi}_{2} \mathrm{~S}_{3}$ microsphere and its efficient photocatalytic activity under visible-light irradiation. Trans. Nonferrous Met. Soc. China 28, 2002-2010. https://doi.org/10.1016/S1003-6326(18)64844-7

Zhao, M., Xiu, G., Qiao, T., Li, Y., Yu, J. (2016). Characteristics of haze pollution episodes and analysis of a typical winter haze process in Shanghai. Aerosol and Air Qual. Res. 16, 1625-1637. https://doi.org/10.4209/aaqr.2016.01.0049

Zhu, Y., Zhu, R., Zhu, G., Wang, M., Chen, Y., Xi, Y., He, H. (2017). Plasmonic Ag coated Zn/Ti-LDH with excellent photocatalytic activity. Appl. Surf. Sci. 433, 458-467. https://doi.org/10.1016/j. apsusc.2017.09.236 